\author{
Available online at http://bajas.edu.iq \\ https://doi.org/10.37077/25200860.2019.251 \\ College of Agriculture, University of Basrah
}

\section{Basrah Journal of Agricultural Sciences}

ISSN $1814-5868$

Basrah J. Agric. Sci., 32(Spec. Issue 2): 1-6, 2019

E-ISSN: 2520-0860

\title{
Xylitol Production from Agricultural Wastes by Candida tropicalis
}

\author{
Raed S. Khudhair ${ }^{1 *} \&$ Elham I. Tami \\ ${ }^{1}$ Department of Biology, College of Education for Pure Science, University of Thi-qar, Iraq. \\ ${ }^{2}$ Department of Food Science, College of Agriculture Engineering Sciences, University of \\ Baghdad, Iraq. \\ *Corresponding author e-mail: ra1973ed@gmail.com \\ Received 19 September 2019; Accepted 18 November 2019; Available online 22 November 2019
}

\begin{abstract}
Xylan produced various agricultural residues including wheat (Furat, Abugraib and Abaa), Papyrus and Sunflower stalks in different ways, including the use of diluted acid, dilute base and self-degradation. The results showed that the acidic method in the production of xylan from various agricultural residues compared with other methods was superior, the highest quantity of xylan $187.6 \mu \mathrm{g} \cdot \mathrm{ml}^{-1}$ was obtained from the agricultural waste of Papyrus, while it was $157.6,157.6,161.6$ and $161.3 \mu \mathrm{g} . \mathrm{ml}^{-1}$ of wheat category of furat, wheat Abu Ghraib, wheat Abaa and sunflower stalks respectively, based on the results obtained, the xylan produced by the acidic method of the different agricultural residues was selected to determine the optimal carboon source for production of xylanase using bacteria Bacillus subtilis strain RS1 locally isolated. After the production of xylitol, the descriptive diagnosis was performed using an HPLC device, depending on the time of the 38.4 minute time lapse reaction of the standard Xylitol and compared with the time of the production of Candida tropicalis, the amount of the processed xylitol was $8.3 \mu \mathrm{g} \cdot \mathrm{ml}^{-1}$, the calculated xylitol was compared standard xylitol.
\end{abstract}

Keyword: Agricultural waste, Xylanase enzyme, Submerged fermentation.

\section{Introduction}

Xylitol $\left(\mathrm{C}_{5} \mathrm{H}_{12} \mathrm{O}_{5}\right)$ is a five carbon suger polyalcohol, obtained from xylose, it is found in small amount in various fruits, vegetables, algae and mushrooms, it is sweetening power similar to that of sucrose, having one third less calorie content (Walsh et al., 2018). Xylitol is used as an alternative sweetener in the food, pharmaceutical and personal care, it is has lower energy (about $40 \%$ fewer calories than the amount found in sucrose), it absorbs slowly from digestive tract and enters the metabolic pathway independently of insulin. So used as a sweetener in dietetic food for diabetics (Mohamad et al., 2015). Xylitol is utilized in the dental industry, as anticariogenic and biomedical properties (Vallejos et al., 2016).

Industrially xylitol is produced by catalytic hydrogenation of D-xylose under high temperature and pressure, biotechnological xylitol production is a replacement for chemical process, as it occurs under milder 
process conditions and utilizes agricultural and forestry wastes which offer the possibilities of economic production of xylitol (Dasgupta et al., 2017). Xylose is produced from agricultural material (hemicellulose fraction) by enzymatic and chemical hydrolysis and converted to xylitol by yeast strain belonging to Candida genus (Asada et al., 2015). The aim of this study is produce a natural sweetner (xylitol) with low calories from agricultural wastes.

\section{Materials \& Methods}

\section{Extraction of xylan from Papyrus, Wheat Furat, Wheat Abugraib, Wheat Abaa and Sunflower stalks}

Five different strategies were applied to each biomass (papyrus, wheat furat stalks, wheat abugraib stalks, wheat abaa stalks and sunflower stalks) in order to recover maximum amount of xylan from raw biomass.

\section{Extract of xylan with diluted acid}

According to the diluted acid extract was applied with slight modification of method of Yang et al. (2005). biomass was diluted acid with $\left(0.01 \mathrm{M} \mathrm{H}_{2} \mathrm{SO}_{4}\right)$ and incubated at $60 \mathrm{C}$ for $12 \mathrm{~h}$. The with distilled water until draw and dried in the oven, then distilled water was added to the biomass by 1:3 (w/v) and put the mixture in autoclave for $1 \mathrm{~h}$, dry the output and grinding in an electric mill to obtain xylan powder.

\section{Extract of xylan with diluted alkali}

The mixture was drain by mixing $50 \mathrm{~g}$ of biomass separately with $80 \mathrm{ml}$ of $1.25 \mathrm{M}$ $\mathrm{NaOH}$ for $10-15 \mathrm{~min}$. then the mixture incubated in a shaker with $150 \mathrm{rpm}$ at $37^{\circ} \mathrm{C}$ for $3 \mathrm{~h}$ and centrifuged at $8500 \mathrm{x} \mathrm{g}$ for 20 min, taking the filtrate modulation to $\mathrm{pH} 5$ with concentrated $\mathrm{HCl}$ and using as substance mainly for enzymatic degradation (Yoon et al., 2006).

\section{Extraction of xylan by autohydrolysis}

The biomass was soak separately with distilled water in a ratio of 1:8 (w/v) and the slurry was autoclaved at $121 \mathrm{C}$ and $15 \mathrm{lbs}$ for $1 \mathrm{~h}$, mix the mixture with muslin cloth, adjust the filtrate and $\mathrm{pH} 5$ using concentrated $\mathrm{HCl}$ and use substance mainly for enzymatic degradation (Tan et al., 2008).

\section{Quantification of xylan extracted from agricultural wastes}

Xylan was quantified extracted according to the method reported by (Dubois et al., 1956), based on the of method phenol-sulfuric acid to estimate total sugars represents the amount of xylan extracted from the biomass.

\section{Microorganism}

Bacillus subtilis bacteria isolated locally from soil, which produce xylanase enzyme, were used to convert xylan to xylose, the $\mathrm{pH}$ was adjusted to 7 and the infestation was sterilized and the production was irrigated by $1 \mathrm{ml}$ of bacterial suspension by $1 \times 10^{7}$ cell.ml ${ }^{-1}$ an incubated in an $37^{\circ} \mathrm{C}$ and shaking incubator and $150 \mathrm{rpm}$ for $48 \mathrm{~h}$, and then used a Candida tropicalis yeast and obtained from Iranian Biological Resource Center (IBRC) in Tehran, producing xylose reductase enzyme to convert xylose to xylitol, the $\mathrm{pH}$ was adjusted to 6 and the infestation was sterilized and the production was irrigated by $10 \mathrm{ml}$ of yeast suspension by $1 \times 10^{6}$ cell.ml $\mathrm{m}^{-1}$ an incubated in a $30{ }^{\circ} \mathrm{C}$ and shaking incubator and $150 \mathrm{rpm}$ for $48 \mathrm{~h}$.

\section{Identification of Xylitol by High Performance Liquid Chromatography (HPLC)}

High performance liquid chromatography was used in the identification of xylitol production 
by Candida tropicalis yeast (Rao et al., 2008). This method was used in the qualitative and quantitative estimation of xylitol as follows:

Qualitative and quantitative estimation of xylitol using the $8 \times 300 \mathrm{~mm}$ Eurokat $\mathrm{H}$ column and the refractive index (RI) for alcoholic sugars, the size of the injected model was $20 \mu \mathrm{l}$, use the high performance liquid chromatography for the chemistry laboratory, Department of Food Science, Faculty of Agriculture, University of Ferdowsi.

The test was performed using the mobile phase of the solution of $100 \%$ sulfuric acid

Table (1): Quantity of xylan extracted from different agricultural waste using different methods.

\begin{tabular}{|c|l|c|c|c|}
\hline \multicolumn{2}{|l|}{ Agricultural wastes } & \multicolumn{3}{l}{ Quantity of Xylan $\left(\mu \mathrm{g} . \mathrm{ml}^{-1}\right)$} \\
\cline { 3 - 5 } \multicolumn{2}{l|}{} & Dilute Acid & Dilute Alkali & Autohydrolysis \\
\hline \multirow{3}{*}{ Wheat } & Furat & 157.6 & 89.3 & 78.1 \\
\cline { 2 - 5 } & Abugraib & 157.2 & 88.1 & 75.2 \\
\cline { 2 - 5 } & Abaa & 161.6 & 93.7 & 82.2 \\
\hline Papyrus & 187.6 & 102.3 & 94.6 \\
\hline Sun Flower Stalks & 161.3 & 90.5 & 82.3 \\
\hline
\end{tabular}

There has been a lot of research on the extraction of xylan from agricultural waste for use in the production of xylanase enzyme, Sporck et al. (2017) used alkali and enzymatic methods in extracting xylan from sugar cane and found superiority of the alkali method with a recovery rate of xylan $53 \%$, in the enzymatic method $22 \%$, while Hauli et al. (2013) used the alkali method in extracting the xylan from different sources and obtained different retrieval rates, the highest was sugar cane with $49 \%$ recovery, $42 \%$ wheat stalks,
$(\mathrm{pH} 2.0 \pm 0.1)$. the separation was performed at room temperature at flow rate of 0.15 ml. $\mathrm{min}^{-1}$.

\section{Result \& Discussion}

\section{Extraction of xylan from Agricultural wastes}

Table (1) showed that the acid yield in the extraction of xylan from agricultural waste compared to other methods, and the highest quantity of xylan $187.6 \mu \mathrm{g} . \mathrm{ml}^{-1}$ obtained from the agricultural waste of papyrus, while 157.6, 157.2, 161.6 and $161.3 \mu \mathrm{g} . \mathrm{ml}^{-1}$ of wheat furat, wheat abugraib, wheat abaa and sunflower stalks respectively. 
Khudhair \& Tami / Basrah J. Agric. Sci., 32(Spec. Issue 2): 1-6, 2019

Several researchers used HPLC in the diagnosis of xylitol. Rao et al. (2008) reported using in the diagnosis of xylitol produced using Candida tropicalis OMV5 using SHDEX SC $10118 \times 300 \mathrm{~mm}$ column and detection WATERS 410 using mobile phase using water at $80{ }^{\circ} \mathrm{C}$ flow rate of $0.5 \mathrm{ml} \cdot \mathrm{min}^{-1}$, while Furlan \& de Castro (2001) identified the diagnosis of xylitol using HPLC using Candida tropicalis using the Interaction Ion 300 column, the mobile phase of the hydrochloric acid solution was 0.025 molar, while Hernandez-Perez et al. (2016)

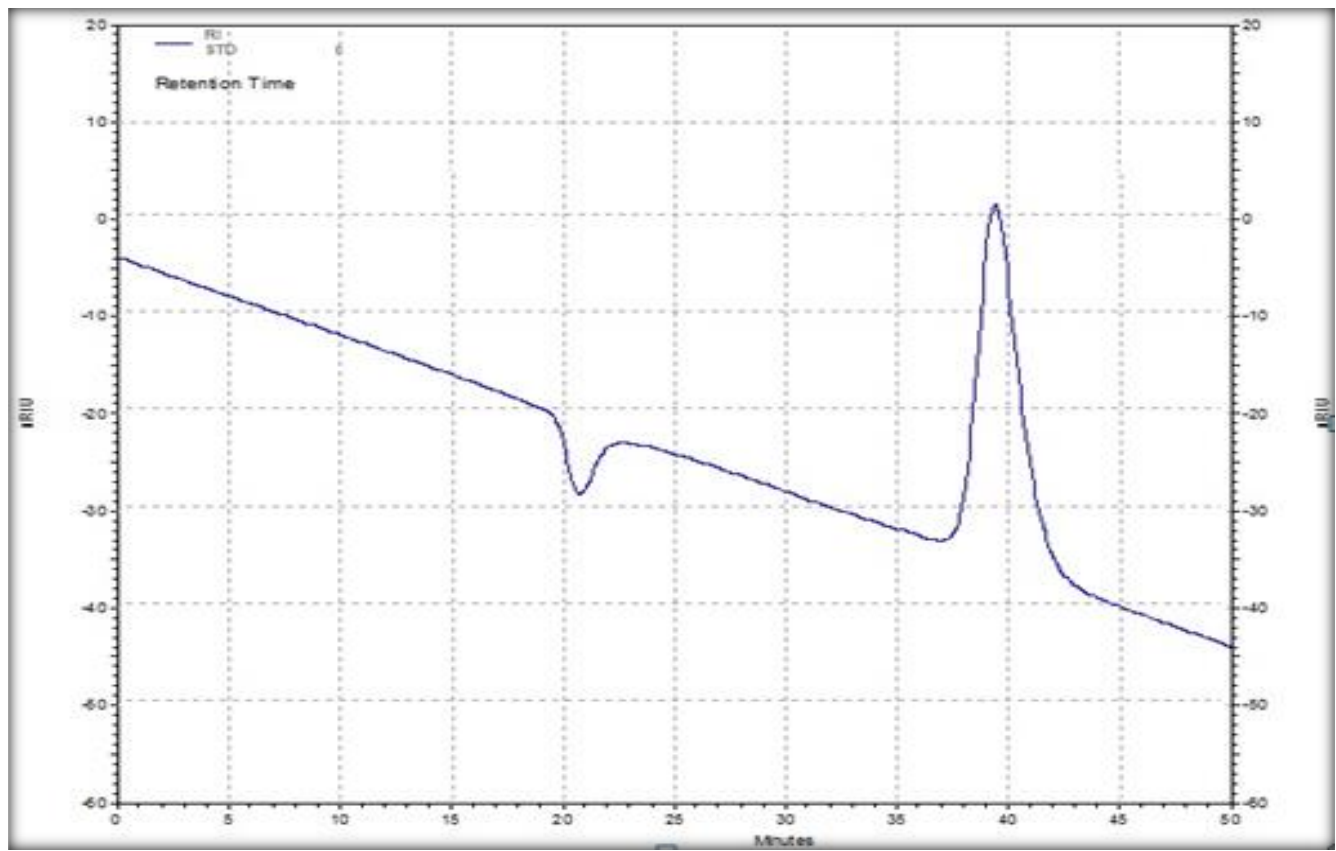

Fig. (1): High Performance Liquid Chromatography of the standard xylitol sample.

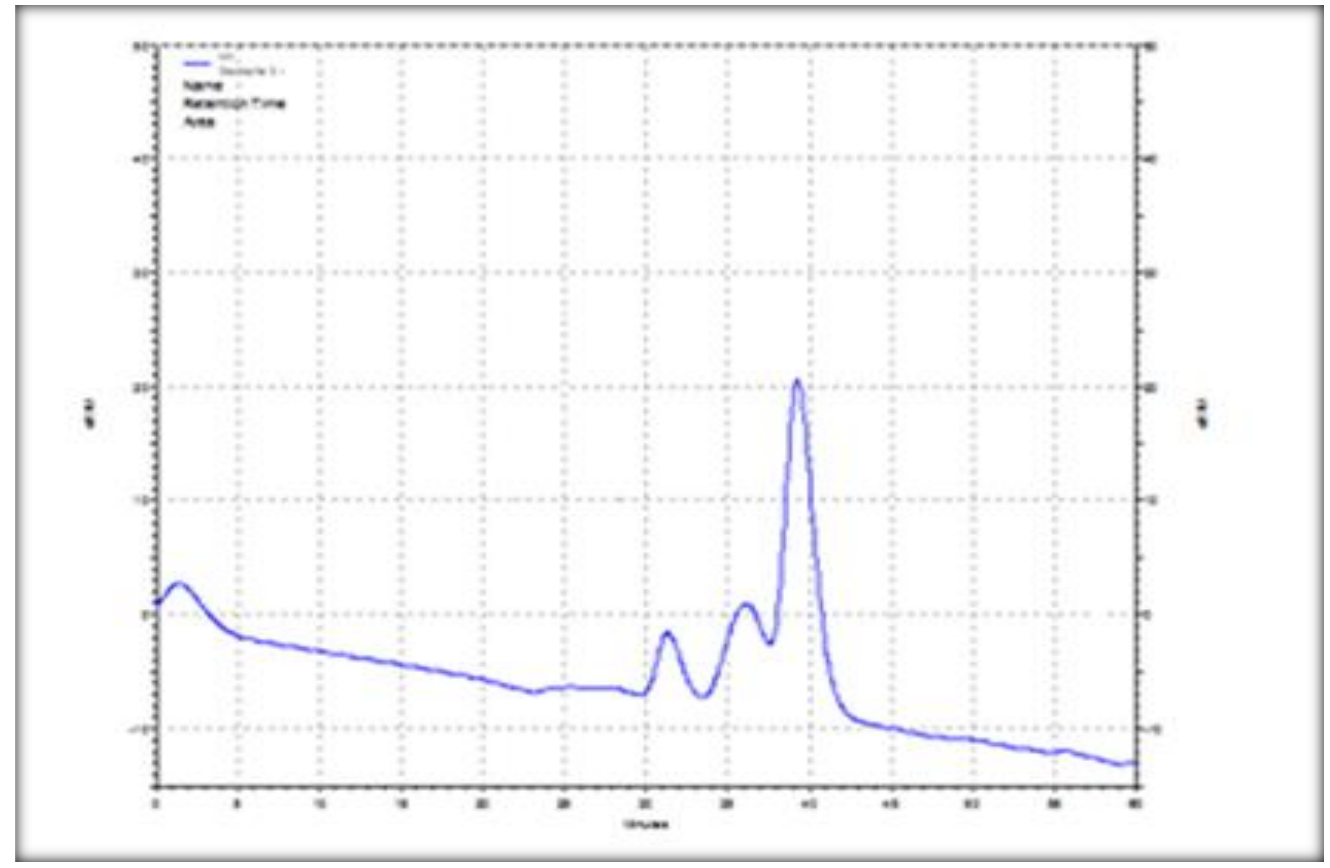


Khudhair \& Tami / Basrah J. Agric. Sci., 32(Spec. Issue 2): 1-6, 2019

Fig. (2): High Performance Liquid Chromatography produced from Candida tropicalis yeast using xylitol produced from papyrus xylan, the calculated xylitol was compared to standard xylitol.

identified the diagnosis of xylitol, xylose, glucose, arabinose, acetic acis, glycerol and ethanol using HPLC using Candida guilliermanii yeast using the Aminex HPX-87 column and the Refractive Index and conducting the test using the mobile phase of the water solution for sulfuric acid $0.01 \mathrm{~N}$ at $45 \mathrm{C}$ and a flow rate $0.5 \mu \mathrm{g} \cdot \mathrm{min}^{-1}$.

\section{Conclusions}

The best method for extracting xylan is the acidic method compared to the alkali method and the method of autohydrolysis using different sources of agricultural residues, and the diagnosis of xylitol by High Performance Liquid Chromatography (HPLC).

\section{Acknowledgements}

I would like to extend my thanks and appreciation to Department of Food Science, College of Agricultural Engineering Science, University of Baghdad to cooperate with me and allow work in their labs.

\section{References}

Asada, C.; Basnet, S.; Otsuka, M.; Sasaki, C. \& Nakamura, Y. (2015). Epoxy resin synthesis using low molecular weight lignin separated from various lignocellulosic materials. Int. J. Biol. Macromol., 74: 413-419.

Dasgupta, D.; Bandhu, S.; Adhikari, D. \& Ghosh, D. (2017). Challenges and prospects of xylitol production with whole cell bio-catalysis: A review. Microbiol. Res., 197: 9-21.

Dubois, M.; Gilles, K.A.; Hamilton, J.K.; Robers. P.A. \& Smith, F. (1956). Colorimetric method for determination of sugars and related substances. Anal. Chem., 28: 350-356.

Furlan, S.A. \& de Castro, H.F.D. (2001). Xylitol production by Candida parapsilosis under fed-batch culture. Braz. Arch. Biol. Techn., 44(2): 125-128.

Hauli, I.; Sarkar, B.; Mukherjee, T.; Chattopadhyay, A. \& Mukhopadhyay, S.K. (2013). Alkaline extraction of xylan from agricultural waste, for the cost effective production of xylooligosaccharides, using thermoalkaline xylanase of thermophilic Anoxybacillus sp. Ip-C. Int. J. Pure Appl. Biosci., 1(6): 126-131.

Hernandez-Perez, A.F.; de Arruda, P.V. \& Almeida Felipe, M.D.G. (2016). Sugarcane straw as a feedstock for xylitol production by Candida guilliermondii FTI 20037. Braz. J. Microbiol., 47(2): 489-496.

Mohamad, N.L.; Kamal, S.M. \& Mokhtar, M.N. (2015). Xylitol bioproduction: A review of recent studies. Food Rev. Int., 31: 74-89.

Rao, R.S.; Jyothi, C.P. \& Rao, L.V. (2008). Biotechnological production of xylitol by mutant Candida tropicalis OMV5: Pross optimization using statistical approach. Indian Biotechnol., 7: 218-224.

Ratanadewi, A.A.; Handadayani, W.; Oktavianawati, I.; Santoso, A.B. \& Puspanigsih, N. (2016). Isolation and hydrolysis xylan from soybean waste with Endo- $\beta-1,4$-xylanase of Bacillus sp. from soil termite abdomen. Agric. Agric. Sci. Proc., 9: 371-377.

Sporck, D.; Reinoso, F. A.; Rencoret, J.; Gutiérrez, A.; Rio, J. C.; Ferraz, A. \& 
Khudhair \& Tami / Basrah J. Agric. Sci., 32(Spec. Issue 2): 1-6, 2019

Milagres, A.M. (2017). Xylan extraction from pretreated sugarcane bagasse using alkaline and enzymatic approaches. Biotechnol. Biofuels, 10(1): 296.

Tan, S.S.; Li, D.Y.; Jiang, Z.Q.; Zhu, Y.P.; Shi, B. \& Li, L.T. (2008). Production of xylobiose from the autohydrolysis explosion liquor of corncob using Thermoto gamaritima xylanase B (XynB) immobilized $\mathrm{n}$ nickel-chelated Eupergit $\mathrm{C}$. Bioresour. Technol., 99: 200-04.

Vallejos, M.E.; Chade, M.; Mereles, E.B.; Bengoechea, D.I.; Brizuela, J.G.; Felissia, F.E. \& Area, M.C. (2016). Strategies of detoxification and fermentation for biotechnological production of xylitol from sugarcane bagasse. Ind. Crop. Prod., 91: 161-169.

Walsh, M.K.; Khaiaf, H.F. \& Shakir, K.A. (2018). Production of Xylitol from agricultural wastes by enzymatic methods. Am. J. Agricult. Biol. Sci., 13(1): 1-8.

Yang, R.; Xu, S.; Wang, Z. \& Yang, W. (2005). Aqueous extraction of corncob xylan and production of xyloolgosaccharides. LWT-Food Sci. Technol., 38: 677-682.

Yoon, K.Y.; Wodams, E.E. \& Hang, Y.D. (2006). Enzymatic production of pentoses from the hemicelluloses fraction of corn resdues. LWT-Food Sci. Technol., 39: 387-391. 